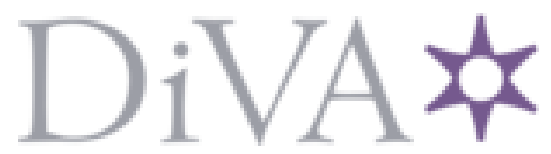

http://www.diva-portal.org

This is the published version of a paper published in British Journal of Economics, Management \& Trade.

Citation for the original published paper (version of record):

Ndikubwimana, P., Berndt, A. (2016)

Service quality and customer satisfaction among bank clients in Rwanda.

British Journal of Economics, Management \& Trade, 13(4): 1-11

http://dx.doi.org/10.9734/BJEMT/2016/26149

Access to the published version may require subscription.

N.B. When citing this work, cite the original published paper.

Open Access journal: http://www.sciencedomain.org/journal/20

Permanent link to this version:

http://urn.kb.se/resolve?urn=urn:nbn:se:hj:diva-32022 


British Journal of Economics, Management \& Trade
13(4): 1-11, 2016, Article no.BJEMT.26149
ISSN: 2278-098X
SCIENCEDOMAIN international
www.Sciencedomain.org

\title{
Service Quality and Customer Satisfaction among Bank Clients in Rwanda
}

\author{
Philippe Ndikubwimana $^{1 *}$ and Adele Berndt ${ }^{2}$ \\ ${ }^{1}$ University of Rwanda, College of Business Economics, Rwanda. \\ ${ }^{2}$ Jönköping International Business School, Gjuterigatan 5, Jönköping, 551-11, Sweden.
}

Authors' contributions

This work was carried out in collaboration between both authors. Author PN designed and executed the data collection. Both authors contributed to the literature review and the final manuscript.

Article Information

DOI: 10.9734/BJEMT/2016/26149

Editor(s):

(1) Jie-hua Xie, NanChang Institute of Technology, Department of Science, China.

Reviewers:

(1) Safdar Husain Tahir, Govt. College University Faisalabad, Pakistan.

(2) Borislav Kolaric, Serbia.

Complete Peer review History: http://sciencedomain.org/review-history/14667

Original Research Article

Received $2^{\text {nd }}$ April 2016

Accepted $11^{\text {th }}$ May 2016

Published 17 $7^{\text {th }}$ May 2016

\section{ABSTRACT}

Despite banking services in Rwanda have low levels of penetration, it is important for banks to focus on providing quality service to their customers. This is due to the effect it has on customer satisfaction and consequently on customer retention. The purpose of the research is to investigate the satisfaction of banking customers in Rwanda with regard to financial services received. This is done through investigation their perceptions of service quality and satisfaction. Little published research among these groups of consumers has been undertaken, making the findings important for the sector in Rwanda. Use was made of a quantitative study using a SERVPERF questionnaire adapted for the Rwandan context to collect data from 156 respondents. Statements on the dimensions of service quality and customer satisfaction were measured using a 7 point Likert scale. The results of study show that the bank's physical environments and facilities are conducive to delivering good service, and the customers are satisfied with the Tangible aspects associated with the service and that they are prepared to reflect this satisfaction in their behaviour. It is recommended that the bank take note of these findings, specifically as they reflect some differences among different groups of customers and incorporate them into future marketing strategies. 
Keywords: Service quality; service quality dimensions; customer satisfaction.

\section{INTRODUCTION}

With globalization and increasing competition, many organisations are putting effort into sustaining and retaining a reliable customer base by delivering service quality and customer satisfaction since these two concepts are central for service organisations. Financial institutions are also attempting to increase their customer satisfaction and loyalty through improved service quality [1-7]. Besides, they suggest that increasing customer retention can have a substantial impact on profits [8-10]. Consequently, they are changing the way they conduct business and adopt new strategies with regard to customers' needs and wants by introducing new financial services.

The introduction of banking services in Rwanda has impacted the banking system and plays a major role in economic growth and development [11]. Research conducted by [12] showed that in general, only 14 percent of the active population use banks, $7 \%$ use Microfinance Finance Institutions, $26 \%$ are informally served and $52 \%$ are financially excluded. This low level of penetration of financial services represents potential growth for the banking sector.

Service quality, customer satisfaction and loyalty in general as well as in the banking sector has received a great deal of attention. Initial studies into service quality and service quality dimensions [13-16,9] have developed into investigation of methods of measurement $[14,17,18]$ as well as the associated behavioural outcomes [19]. Studies have also been conducted into the measurement of these constructs in the banking sector $[1,6,7,20$, $21,22,23,24]$. The introduction of internet (and electronic banking) has required the adaptation and development of measurement tools in this context [25].

Studies have been undertaken in Pakistan [26]; India [27,28,29,30]; Ghana [31]; Ethiopia [32] and Bangladesh [33]. It is to the studies in developing economics that this paper seeks to contribute. The contribution of this research is the investigation that has been undertaken in the Rwandan banking industry. Measurement has been done of perceived service quality in order to examine possible behavioural effects that delivering a quality service can give to banks.

The article commences with the theoretical foundation for the study by examining the relationship between service quality and customer satisfaction. The study is then presented, where after the findings are reported. The paper concludes with a discussion of the implications of the research for the specific bank that is the focus of the study together with implications for the broader banking sector.

\section{THE RESEARCH PROBLEM AND RESEARCH OBJECTIVES}

Rwanda has seen an increase in the number of adults having access to financial services from $21 \%$ in 2008 to $42 \%$ in 2012 [34], yet large numbers of individuals can be described as unbanked. Customers coming into the banking system for the first time translates into consumers with varying expectations and perceptions of services. This impacts their satisfaction with the financial services received.

Research conducted by $[35,36,37]$ revealed that customers complain of inadequacy of services in the use of the banking system such as breakdowns of ATMs, long queues at ATM service points, retention of customers' cards by ATM machine, limited knowledge on the use of ATM cards, fraudulent transactions and ATM operation in just a few languages, lack of connection. According to [38], banks' customers in Rwanda are facing a number of other barriers to financial services access, including: a low level of financial literacy, out-dated payment systems, inadequate financial products and service as well as a lack of appropriate delivery methods (particularly in rural areas).

With the description of current services offered, it is necessary to investigate the level of customer satisfaction among customers of commercial banks in Rwanda. To date, little research has been done in Rwanda on the perception and satisfaction of customers with regard to financial services offered by commercial banks [34]. The problem is that with more customers, BK needs to make sure customers are satisfied. But what is their perception of the service quality, and are they satisfied?

With the importance of service quality and customer satisfaction in the performance of the organisation $[20,28,30]$, it is necessary for banks to provide excellent service. Consequently, the purpose of this research is to investigate the satisfaction of banking customers in Rwanda with regard to financial services received. 


\section{BANKING IN RWANDA}

\subsection{Brief History of the Banking Sector in Rwanda}

The Rwandan financial sector started with the creation of the Central Bank, National Bank of Rwanda in April 1964. According to [39], before the genocide of 1994, the development of the financial sector in Rwanda was weak: only three commercial banks and two specialized banks operated with a total of less than twenty branches in the country, and one microfinance (UBPR) with around one hundred forty six branches. The genocide negatively affected the development of the banking sector and almost both physical and human capital of all banks was destroyed during the genocide [40].

After the genocide the number of banks has increased, where in 2002 there were six commercial banks with twenty eight branches, two specialized banks and one union of financial institutions (UBPR) with one hundred forty eight branches [41]. In 2007, commercial banks operated 38 branches, making only $7 \%$ of all branches of financial institutions. By the end of 2008, 8 commercial banks, 2 specialized banks and 1 Microfinance bank were operating. At the end of 2012, the Rwanda's banking sector was composed of nine commercial licensed banks, three micro-finance banks, one development bank, and one co-operative bank [34].

During this time, the Rwandan financial services industry experienced important development, as economic strength and growth increased employment rates and the purchasing power of the Rwandan population, and this lead to more penetration of financial products and services. Although the number of adults benefiting from banking services was still relatively low $(58 \%)$ in 2008 , this figure increased to $72 \%$ four years later [34].

\subsection{Brief Description of the Bank that is the Focus of the Study}

Founded in 1966 as a joint venture between Belgolaise S.A. and the Government of Rwanda, Bank of Kigali (BK) is now a dominant player in the Rwandan banking sector and is widely regarded as a reliable financial institution with a highly recognised brand and strong reputation for customer focus, outstanding service and robust balance sheet.

The bank has expanded its service delivery channels and developed an array of products that ensure that customers have access to its services twenty four hours a day, seven days a week. Diverse technological driven alternative delivery channels by introducing mobile vans dubbed mobibank to serve five provinces of Rwanda and all the bank's ATMs and Point of Sales accept international cards [42].

By the end of May 2013, BK had 57 branches operating within Kigali city and across the country and 47 ATMs [43]. Bank of Kigali is the leading bank in Rwanda in terms of assets, deposits, loans and shareholders' equity and is also the most profitable bank in Rwanda, accounting for above $50 \%$ of the total banking sector profits in each of the last three financial years. The bank is represented in all provinces and all major economic districts in Rwanda. As of 31 December 2010, the Bank had, after BPR, the second largest branch network in the country with 33 branches [34].

\section{CUSTOMER SATISFACTION AND SERVICE QUALITY}

Organisations have focused a great deal of attention on the issues of customer satisfaction and service quality, with efforts going into determining ways in which these aspects can be measured for an organisation while also suggesting ways in which organisations can improve their operations (and these scores).

\subsection{The Nature of Customer Satisfaction}

In general, satisfaction is a person's feelings of pleasure or disappointment that result from comparing a product's or service's perceived performance or outcome to the expectation $[9,44]$. If the performance falls short of expectations, the customer is dissatisfied. If the performance matches the expectations the customer is satisfied. If the performance exceeds expectations, the customer is highly satisfied and delighted [45].

The concept of customer satisfaction occupies a central position in business relationships. Many have defined with reference to the customer's prior expectations. For instance, [46] defines it as the state of mind that customers have about a company when their expectations have been met or exceeded over the lifetime of the product or service. One can be satisfied by a product and service received, or by the company that offered it, when that product and service, or the provider, has met one's prior expectations. Therefore, a high level of service quality is considered as one 
of the most important determinant in explaining customer satisfaction, which in turn, influences on customer loyalty towards the organisation $[6,26,28,47]$. That is why, in today's high competitive business environment, achieving success will greatly depend on customer satisfaction.

\subsection{Factors Influencing Customer Satisfaction}

According to [48], customer satisfaction is determined by various factors, including perceptions of service and product quality, and price. Other factors like personal and situational factors may influence also customer satisfaction. Although it is stated that other factors such as price and product quality can affect customer satisfaction, perceived service quality is an important component of customer satisfaction [49]. In addition to service quality, other researchers [50] have identified that customer satisfaction is also determined by other factors such as customer specific and situational factors.

\subsection{Service Quality}

Service quality is regarded as the result of the comparison made by customers about what they feel service organisations should offer, and perceptions of the performance of organisations providing the services [9,22]. A customer's expectation serves as a foundation for evaluating service quality because, quality is high when performance exceeds expectation and quality is low when performance does not meet their expectation $[51,52]$. Empirical studies show that the quality of service offered is related to overall satisfaction of the customer.

Service quality is considered an important tool for an organisation's struggle to differentiate itself from its competitors [53]. It is also an important tool to measure customer satisfaction [54]. According to several researchers such as [21], and others, service quality is a function of the customer's expectations (what they expect the organisation should offer them) and what they really get and how they feel about it. In order to measure the customer's perceptions of the service received [13] developed the SERVQUAL instrument which compares the customer's initial expectations and his/her perceptions of the service received.

Service quality can be analysed into five dimensions namely reliability, responsiveness, assurance, empathy, and [13]. Service quality is a focused evaluation that reflects the customer's perception of reliability, assurance, responsiveness, empathy and tangibility, while satisfaction is more inclusive and it is influenced by perceptions of service quality, product price and quality as well as situational factors and personal factors [49].These five dimensions of perceived quality are also the basis upon which expected quality is built. Reliability is the ability of the service provider to perform the promised service dependably and accurately $[49,55]$. Responsiveness reflects of the willingness to help customers and provide prompt service $[18,49]$ and is seen in the timely reaction towards the customers' needs or willingness to provide timely services to customers. In context of the Bank, this refers to the changes that have been observed in financial service like introduction of electronic banking, mobile banking, and ATM services in order to respond to the needs of customers. Assurance quality is a knowledge and courtesy of employees and their ability to inspire trust and convey confidence among customers. Empathy is a quality which is the last dimension on SERVQUAL model. It is the ability to be approachable, and giving individual attention to the customers [22,49]. Tangibility is a concept that measures how dependable a customer views a service provider to be based upon the quality of its most visible attributes [49].

In the banking sector, service quality has become more and more significant aspect for achievement and endurance $[6,19,56]$. The stipulation of high quality service helps in achieving numerous requirements like customer satisfaction and its outcome loyalty, profitability, market share and financial performance.

Once the customer has chosen a commercial bank, they have developed expectations of what constitutes service, an ideal service level [49]. This is then used in the evaluation of the actual service, resulting in a confirmation/ disconfirmation of the service.

\subsection{Measuring Customer Satisfaction and Service Quality}

\subsubsection{Measuring of customer satisfaction}

Customer satisfaction has been described by organisations as a critical factor in this success. Measuring satisfaction is generally linked to the so-called confirmation/disconfirmation process that comes about when customers believe that 
their expectations have been met [50]. Associated with this are the expectations and perceptions of customers and the actual experiences of the customer, which in turn produces a level of perceived quality that is influenced by expectations [44].

Satisfaction can be determined by subjective (e.g. customer needs, emotions) and objective factors (e.g. product and service features). Service quality and customer satisfaction are distinct concepts, although they are closely related. Various researches have been done to measure customer satisfaction in service industry.

The search done by [57] found that "cleanliness, security, value for money and courtesy of staff determine customer satisfaction". [58] revealed that cleanliness and comfort, convenience of location, prompt service, safety and security, and friendliness of employees are key determinants of customer satisfaction. A study conducted by [15] claimed that the vital factors are the behaviour of employees, cleanliness and timeliness. On the other hand the study by [59] concluded that staff quality, property qualities, and value are the top three factors that determine customers' satisfaction.

\subsubsection{Measuring service quality}

It exist many service quality models but scientists do not have similar view about these models and their measurements. Service quality has diverse dimensions in varying service sectors [60]. However, service quality measurement enables managers to recognize quality problems and enhance the efficiency and quality of services to exceed expectations and reach customer satisfaction [61].

The most widely used scales in measuring service quality in the banking sector are the SERVQUAL and SERVPERF models $[17,32,56]$. [14] developed an instrument SERVQUAL that has the greatest in the measurement of service quality. According to the SERVQUAL model, service quality can be measured by identifying the gaps between customers' expectations of the service to be given and their perceptions of the actual performance of the service. SERVQUAL instrument involves the measurement of the five dimensions. The respondent is capable to specify both perceptions and expectations that statements have of the specific dimension [14] made use of 7 point scale to determine both perceptions and expectations. The foundation of SERVQUAL is the conceptualization of service quality as the difference between customers' expectations and perceived performances.

The SERVPERF instrument was introduced by [17]. SERVPERF measures service quality by measuring the perceptions of customers. Cronin and Taylor argued that measuring perceptions are sufficient for measuring service quality and therefore expectations should not be included as suggested by SERVQUAL [23]. The SERVPERF instrument is a derivative of the original SERVQUAL instrument, only measuring performance of service quality. The improvement offered by SERVPERF includes the absence of gap measurement issues, greater variance explained, and a smaller number of items used $[17,21]$.

The evaluation of service quality is conceptualized as a gap between what the customer expects from banks with regards to financial services and their assessments of the performance with the Bank. The SERVPERF in this study was adapted to Rwanda banking industry to measure service quality as perceived by the customers.

\section{RESEARCH METHODOLOGY}

This part provides a detailed analysis of the methodology which has been used by the researcher to collect data, analyse them and the presentation of the findings. Quantitative research was used. The quantitative research is the technique that involves a large number of respondents providing descriptive evidence that cannot be simply projected on whole population [62]. This research undertakes a survey involving customers of one of leading banks in Rwanda. The questionnaire was a self-completion questionnaire: The respondent completed it without any assistance.

\subsection{Population and Sampling}

The population to be used in this study covers the customers of the bank. Non-probability sampling was used. Non-probability sampling represents a group of sampling techniques that help researchers to select units from a population that they are interested in studying [63]. Respondents were selected using convenience sampling method due to a potentially infinite population. This means that customers were selected due to the ease with which they could be contacted. The researcher requested 
permission from the bank to engage customers in the study through giving them questionnaires to fill them as they come to the bank before they went out.

\subsection{Sources of Data and Data Collection Instruments}

The research used both primary and secondary data. Primary data were selected for respondents using questionnaires. Secondary data were obtained by reviewing existing published literature.

The instrument of this study was constructed on the basis of research objectives and research questions where a bibliographical section was to obtain information about the respondents. Information gathered through questions related to the customers' gender, age, occupation and the time which they have been customer of the Bank. The instrument was adapted to the Rwandan commercial bank situation and was translated into Kinyarwanda. Use was made of a 7 point Likert scale.

\subsection{Data Processing and Analysis}

The researcher closely examined the relationship between the questions and their respective responses in order to ensure consistency, accuracy and uniformity. Quantitative techniques were used to process and analyse the collected data. Using these techniques, the presentation and organization of findings made it very easy to comprehend and draw conclusions based on the findings.

Data collected have been categorized in different categories by which answers to each question in a completed data collection instrument, is categorized and codified. These were presented or summarized or condensed into tables and graphs for analysis purposes. The data was then analysed using statistical methods in order to interpret them. Tests used included descriptive statistics, tests for reliability, ANOVAs and ttests.

\section{FINDINGS}

Responses were received from 156 customers of the bank of Kigali.

\subsection{Demographic Findings}

The respondents included more males (67.9\%) than females $(32.1 \%)$. Nearly one third of the respondents (32.1\%) is aged between 35 and 54 .
There were more married (54.5\%) respondents, and the majority of the respondents had completed university (53.8\%). The greatest number of respondents have been BK's customer for 1 to 3 years (42.3\%). Regarding the frequency of use BK's facilities, one third were using ATM and Mobile banking $(39.1 \%$ and $32.1 \%$ ) respectively. Table 1 provides further detail on the respondents.

\subsection{Customer Perceptions of Service Quality in BK}

The scores on the individual items and on the dimensions are presented in Table 2. From this table it can be seen that all the dimensions are positively perceived by the respondents, with the score on the Tangibles items as the highest (mean=5.812; SD=0.776). The respondents describe themselves as being satisfied (mean=6.030) and their stated intentions towards the bank are positive (mean=6.451; $S D=0.316$ ).

To determine whether there were significant differences between the groups with regards to the various dimensions, use was made of t-tests and ANOVAs. An independent samples t-test was conducted to compare the genders with regards to the service quality dimensions. Statistically significant differences were found between males $(M=4.81 ; S D=0.859)$ and females $(M=5.29 ; S D=0.833 ; t(156)=-3.77 ; p=0.001)$ with respect to the Empathy dimension. The magnitude of the differences in the means was moderate (eta squared $=0.0651$ ). Statistically significant differences between the genders were also found with respect to Customer Satisfaction [Males: $(M=6.08 ; \quad S D=0.408)$ and Females: $(M=5.93 ; S D=0.347 ; t(156)=2.323, p=0.021)$ with a moderate effect (eta squared $=0.0752$ ).

ANOVAs were used to determine whether there were differences between the age groups. Significant differences were found between those in the age group 18-25 and in another age group with respect to the Tangibles dimension $[F(5$, 148)=7.057, $p=0-.000]$. The effect size, calculated using eta squared, was 0.0752 . Posthoc comparisons using the Tukey test indicated that the mean score those aged 18-25 ( $M=5.31$; $S D=0-572)$ was significantly different from those aged 35-54 ( $M=5.90, S D=0.837)$.

\subsection{Reliability of Overall Model and Quality Dimensions}

To test reliability between variables, Cronbach's Alpha has been used (it varies between 0 and 1). 
Cronbach's Alpha has been used to measure internal consistency, which means that all items within the model should measure the same construct. The closer the value is to 1.0 , the greater the internal consistency of items in the model being assessed [64].

Table 1. Demographic characteristics of the respondents

\begin{tabular}{|c|c|}
\hline Characteristic & Distribution \\
\hline Gender & $67.9 \%$ male; $31.1 \%$ female \\
\hline Age & $\begin{array}{l}16 \% \text { aged } 18-25 ; 18.6 \% \text { aged } 26-34 ; 32.1 \% \text { aged } 35-54 ; 16 \% \text { aged } 55-64 ; 1.9 \% \\
\text { older than } 65 ; 15.4 \% \text { not willing to say; }\end{array}$ \\
\hline Marital status & $19.9 \%$ single; $54.5 \%$ married; $25.6 \%$ not willing to say; \\
\hline Educational level & $\begin{array}{l}1.9 \% \text { some primary school; } 3.8 \% \text { some secondary school; } 23.1 \% \text { some university; } \\
7.1 \% \text { technical degree/diploma; } 53.8 \% \text { degree completed; } 10.3 \% \text { not willing to } \\
\text { say; }\end{array}$ \\
\hline Branches of clients & $\begin{array}{l}50 \% \text { Kigali City; } 9.6 \% \text { Northern Province; } 14.1 \% \text { Eastern Province; } 19.2 \% \\
\text { Southern Province; 7,1\% Western Province; }\end{array}$ \\
\hline $\begin{array}{l}\text { Length of time as a bank } \\
\text { clients }\end{array}$ & $\begin{array}{l}12.2 \% \text { less than } 1 \text { year; } 42.3 \% 1-3 \text { years; } 19.2 \% 4-7 \text { years; } 11.5 \% 8-11 \text { years; } \\
14.7 \% \text { more than } 12 \text { years; }\end{array}$ \\
\hline Use of bank facilities & $\begin{array}{l}39.1 \% \text { use the ATM; } 13.5 \% \text { Visa card; } 32.1 \% \text { mobile banking; } 8.3 \% \text { cheque book; } \\
7.1 \% \text { other; }\end{array}$ \\
\hline Frequency of ATM usage & $\begin{array}{l}44.9 \% \text { never; } 30.8 \% 1-2 \text { times; } 15.4 \% 3-4 \text { times; } 5-6 \text { times } 5.1 \% \text {; more than } 6 \\
\text { times } 3.8 \%\end{array}$ \\
\hline Internet usage per month & $\begin{array}{l}7.7 \% \text { never; } 15.4 \% 1-2 \text { times; } 26.3 \% 3-4 \text { times; } 42.3 \% \text { 5-6 times; } 8.3 \% \text { more than } \\
6 \text { times; }\end{array}$ \\
\hline
\end{tabular}

Table 2. Customer perception of BK's service quality

\begin{tabular}{|c|c|c|}
\hline & Mean & $\begin{array}{l}\text { Standard } \\
\text { deviation }\end{array}$ \\
\hline Tangible & 5.812 & 0.776 \\
\hline BK's physical facilities are visually appealing & 5.365 & 1.354 \\
\hline BK uses state of the art technology and equipment in their service delivery & 6.205 & 1.217 \\
\hline The employees are well dressed and neat in appearance. & 5.865 & 1.136 \\
\hline Reliability & 4.934 & 0.874 \\
\hline BK always honours its promises. & 5.038 & 1.485 \\
\hline When I have a problem, BK shows sincere interest in solving it & 4.692 & 1.485 \\
\hline BK delivers its services promptly at the time it promises to do so. & 5.071 & 1.485 \\
\hline Responsiveness & 5.131 & 1.117 \\
\hline BK's employees tell me exactly when services will be performed. & 5.122 & 1.336 \\
\hline BK's employees are always willing to help me. & 5.141 & 1.336 \\
\hline Assurance & 5.473 & .478 \\
\hline BK's employees instill confidence in me. & 5.885 & 1.053 \\
\hline I feel safe in transactions with the bank. & 6.279 & 1.053 \\
\hline BK's employees are consistently courteous with me. & 5.365 & 1.053 \\
\hline BK's employees have knowledge to answer my questions. & 4.361 & 1.053 \\
\hline Empathy & 4.962 & .627 \\
\hline BK's employees give me individual attention. & 4.85 & 1.359 \\
\hline BK's employees understand my specific needs. & 5.01 & 1.205 \\
\hline BK operating hours and location are convenient to me. & 5.03 & 1.056 \\
\hline Overall service quality - The services offered by BK are of high quality. & 5.949 & \\
\hline Customer satisfaction & 6.030 & 0.395 \\
\hline $\begin{array}{l}\text { I am satisfied about the use of electronic banking services (e.g.: ATM-Internet- } \\
\text { Mobile Banking). }\end{array}$ & 6.276 & 0.913 \\
\hline Bk does not cost too much. I pay a fair price for my banking services & 6.276 & 0.913 \\
\hline Internet connections is always available & 6.276 & 0.913 \\
\hline I feel delighted with BK's services. & 6.276 & 0.913 \\
\hline Behavioural intentions of customer & 6.451 & 0.316 \\
\hline I will say positive things about my bank to other people. & 6.413 & 0.709 \\
\hline I would like to keep close relationship with my bank. & 6.413 & 0.709 \\
\hline I consider myself to be loyal to my bank. & 6.413 & 0.709 \\
\hline I think BK is the best bank. & 6.413 & 0.709 \\
\hline
\end{tabular}


Table 3. Overall reliability

\begin{tabular}{ll}
\hline Quality dimensions & Cronbach's alpha \\
\hline Tangible & 0.226 \\
Reliability & 0.414 \\
Responsiveness & 0.508 \\
Assurance & 0.129 \\
Empathy & 0.544 \\
Overall Model reliability & 0.373 \\
\hline
\end{tabular}

The reliability of this study is to measure customer satisfaction with regards to service quality offered by the bank. The Alpha coefficient shows that the reliability of empathy and responsiveness as quality dimensions are 0.544 and 0.508 respectively. As has been calculated in the above table showing the reliability of overall model and quality dimensions is 0.373 . The results above show that both overall model and reliability dimensions can be considered as to have low reliability, which impacts on the extent to which analysis can be conducted and conclusions drawn.

\section{DISCUSSION}

The findings show that customers perceive the service received from the bank positively, as they are reflected in the dimensions of service quality. Service quality and customer satisfaction occupies a central position in business activities, which emphasises the purpose of this research in investigating these aspects. The findings are consistent with previous studies that service quality is an important part of having satisfied customers in the banking context $[1,6]$. Measuring the service quality dimensions (using SERVPERF) has indicated the perceptions of customers with respect to services offered by Bank of Kigali in Rwanda. Based on the study, it was revealed that, BK employees had skills and knowledge in the performance of the services to customers. Customers feel respected and have generated feelings of security with bank, highlighting the importance of human contact $[27,28]$. Considering the quality dimensions, the largest perceptions of Bank of Kigali were in terms of the tangibility dimension. This differs from other studies but this can be ascribed to the location in which the research was undertaken [28].

All banks strive to deliver service quality at it can provide competitive advantage $[1,6,26,28]$. But to provide this requires action on the part of management. Having a good recovery process for a dissatisfied customer or service failure is a very important and necessary process for any service organization like Bank of Kigali, and continual development and improvement of this process is necessary. Customer satisfaction as it reflects in specific behaviours are also positive towards the bank, and as word-of-mouth is critical in services, this aspect cannot be ignored by the bank. Financial services that are provided are positively perceived specific strategies needs to be developed in order to retain customers, one of the strategies is to increase number of bank's outlets during taxes payment periods. While employees are perceived to be skilled, the bank needs to ensure that they continue training to ensure that employee skills are at an optimal level.

There are a number of limitations associated with the study. It was conducted in one commercial bank in Rwanda, which cannot be regarded as representative of other commercial banks in Rwanda. This means that the results of this study cannot be generalized. Low levels of reliability in the survey also impacted the results.

For further research, little research has been published regarding service quality and customer satisfaction in commercial bank sector in Rwanda. Research needs to be done in customer satisfaction with other factors including personal factors, price, product quality, situational factors and in other financial service industry of Rwanda. Further research also needs to be done into use of the applicability of other service quality and customer satisfaction instruments in the Rwandan context.

\section{CONCLUSION}

Service quality and customer satisfaction are important constructs in service industries, and this is also the case in banking. The purpose of this research was to investigate the satisfaction of banking customers in Rwanda with regard to financial services received, and the investigation of these perceptions of Rwandan banking customers regarding service quality and satisfaction has indicated positive perceptions. While service quality perceptions of customers are largely positive, maintaining these positive perceptions is important for the continued satisfaction of both existing customers while also providing satisfaction to new customers. This would be done through the continued attention to interaction-related aspects (such as employees). 


\section{DISCLAIMER}

This manuscript was presented in the conference "1 ${ }^{\text {st }}$ Annual Eastern Africa Business and Economic Watch-2015" available link is "http://www.divaportal.org/smash/get/diva2:8111 74/FULLTEXT01.pdf." date April 5-7 - May 2015, Kigali.

\section{COMPETING INTERESTS}

Authors have declared that no competing interests exist.

\section{REFERENCES}

1. El Saghier N, Nathan D. Service quality dimensions and customers' satisfactions of banks in Egypt. 20 ${ }^{\text {th }}$ International Business Research Conference; 2013.

2. Bloemer J, De Ruyter K, Peeters P. Investigating drivers of bank loyalty: The complex relationship between image, service quality and satisfaction. International Journal of Bank Marketing. 1998;16(7):276-286.

3. Jamal A, Naser K. Customer satisfaction and retail banking: An assessment of some of the key antecedents of customer satisfaction in retail banking. International Journal of Bank Marketing. 2002;20(4): 146-160.

4. Lassar W, Manolis C, Lassar S. The relationship between consumer innovativeness, personal characteristics, \& online banking adoption. International Journal of Bank Marketing. 2005;23(2): 176-199.

5. McDougall G, Levesque T. Determinants of customer satisfaction in retail banking. International Journal of Bank Marketing. 1996;14(7):12-20.

6. Vera J, Trujillo A. Service quality dimensions and superior customer perceivedvalue in retail banks: An empirical study on Mexican consumers. Journal ofRetailing and Consumer Services. 2013;20:579-586.

7. Zhou L. A dimension specific analysis of performance-only measurement of servicequality and satisfaction in China's retail banking. Journal of Services Marketing. 2004;18(7):34-546.

8. Spreng RA, Mackoy RD. An empirical examination of a model of perceived service quality and satisfaction. Journal of Retailing. 1996;72:201-14.
9. Caruna A. Service loyalty: The effects of Service Quality and the mediating role of Customer Satisfaction. European Journal of Marketing. 2002;36(7/8):811-822.

10. Culiberg $B$, Rojšek I. Identifying service quality dimensions as antecedents to customer satisfaction in retail banking. Economic and Business Review. 2010; 12(3):151-166.

11. MINICOFIN. Annual Report of Ministry of Finance and Economic Planning, Kigali, Rwanda; 2000. January 15, 2015. Available:www.minecofin.gov.rw/

12. Fin Scope. The financial access in Rwanda. Finmark Trust. 2008;1-9. April 10, 2015.

Available:www.statistics.gov.rw

13. Parasuraman A, Zeithaml VA, Berry LL. A conceptual model of service quality and its implications for future research. Journal of Marketing. 1985;49:41-50.

14. Parasuraman A, Zeithaml VA, Berry LL. SERVQUAL: A multi item scale for measuring consumer perception of service quality. Journal of Retailing. 1988;64:1240.

15. Akan P. Dimensions of service quality: $A$ study in Istanbul. Managing Service Quality. 1995;5(6):39-43.

16. Grönroos C. The perceived service quality concept - a mistake? Managing Service Quality. 2001;11(3):150-152.

17. Cronin JJ, Taylor SA. Measuring service quality: A re-examination and extension. Journal of Marketing. 1992;56:55-68.

18. Buttle F. SERVQUAL: Review, critique, research agenda. European Journal of Marketing. 1996;30(1):8-32.

19. Yavas U, Benkenstein M, Stuhldreier U. Relationships between service quality and behavioral outcomes: A study of private bank customers in Germany. The International Journal of Bank Marketing. 2004;22(2):144-157.

20. Newman K, Cowling A. Service quality in retail banking: the experience of two British clearing banks. International Journal of Bank Marketing. 1996;14(6):3-11.

21. Newman K. Interrogating SERVQUAL: A critical assessment service quality measurement in a high street retail bank. International Journal of Bank Marketing. 2001;19(3):126-139.

22. Arasli H, Mehtap-Smadi S, Katircioglu ST. Customer service quality in the Greek Cypriot banking industry. Managing Service Quality. 2005;15(1):41-56. 
23. Petridou E, Charalambos S, Niki G, Chris L. Bank service quality: Empirical evidence from Greek and Bulgarian retail customers. International Journal of Quality \& Reliability Management. 2007;24(6):568-585.

24. Siu NYM, Mou JCW. Measuring service quality in internet banking: The Case of Hong Kong, Journal of International Consumer Marketing. 2005;17(4):99-116.

25. Wu Y-L, Tao Y-H, Yang P-C. Learning from the past and present: Measuring Internet banking service quality. The Service Industries Journal. 2012;32(3): 477-497.

26. Hafeez S, Muhammad B. The impact of service quality, customer satisfaction and loyalty programs on customer's loyalty: Evidence from the banking sector of Pakistan. International Journal of Business and Social Science. 2012;3(16):200-209.

27. Kaura V, Prasad CSD, Sharma S. Impact of service quality, service convenience and perceived fairness on customer satisfaction in Indian retail banking sector. Management and Labour Studies. 2014;39(2):127-139.

28. Choudhury K. Service quality and word of mouth: A study of the banking sector. International Journal of Bank Marketing. 2014;32(7):612-627.

29. Sunny B, Gupta N. Customer perception of services based on the SERVQUAL Dimensions: A study of Indian commercial banks. Services Marketing Quarterly. 2013;34(1):49-66.

30. Yadav MK, Rai AK. Service quality gaps banking industry: A comparative study. KIIT Journal of Management. 2014;10(1): 61-72.

31. Okoe AF, Adjei JS, Osarenkhoe A. Service quality in the banking sector in Ghana. International Journal of Marketing Studies. 2011;5(2):81-92.

32. Mesay SS. Bank service quality, customer satisfaction and loyalty in Ethiopian banking sector. Journal of Business Administration and Management Sciences Research. 2012;1(1):1-9.

33. Uddin MM, Khan MA, Farhana N. Banking services and customer perception in some selected commercial banks in Bangladesh. Indonesian Management and Accounting Research. 2014;13(1):1-15.

34. Ecobank. Ecobank research: Banking in Rwanda, Middle Africa insight series; 2013.
35. Nsengiyumva A, Habumuremyi E. A review of telecommunications policy development and challenges in Rwanda. (Johannesburg: Association for Progressive Communications; 2009.

36. Joseph M, McClure J, Joseph B. Service quality in the banking sector: The impact of technology on service delivery. International Journal of Bank Marketing. 2003;17(4):182-191.

37. Egyeyu $H$. Information technology \& electronic banking in commercial banks in Uganda. Gulu University; 2010. Retrieved February 20, 2015.

Available:www.academia.edu

38. Alliance for financial inclusion. Rwanda's financial inclusion success story: Umurenge SACCOs. AFI publisher. 2014;1-12. April 15, 2015.

Available:www.afi.global.org

39. Dushimyumukiza D. Financial development and economic growth in Rwanda. University of Mauritius; 2010. Memoire online. Retrieved March 27, 2015 Available:www.memoireonline.com

40. Dagne T. Rwanda: Background and Current Developments. Congressional Research Service; 2011.

41. BNR. The Annual Report on Financial Stability, Author; 2004. Retrieved February 10, 2015.

Available:www.bnr.rw

42. The new times. Finance and Banking Sector Review in Rwanda Part; 2013. Available:http://www.newtimes.co.rw/pdf a ds/finance-\&-banking.pdf

(Accessed 1 June 2015).

43. Bank of Kigali prospectus; 2011. Kigali, author. Retrieved March 27, 2015. Available:www.bk.rw

44. Oliver RL. A cognitive model of the Antecedents and consequences of satisfaction decisions. Journal of Marketing Research. 1980;17(4):460.

45. Rahman $\mathrm{MH}$. Factors affecting customer satisfaction in mobile telecommunication industry in Banglades. Business, Management and Education. 2014;12(1): 74-93.

46. Cacioppo K. Measuring and managing customer satisfaction. Quality Digest; 2000.

Available:http://www.qualitydigest.com/sep t00/html/satisfaction.html

(Accessed 29 May 2015)

47. Oliva TA, Oliver RL, MacMillan IC. A catastrophe model for developing service 
satisfaction strategies. Journal of Marketing. 1992;56:83-95.

48. Zeithaml VA, Bitner MJ. Service marketing: Integrating customer focus acrossthe firm, $3^{\text {rd }}$ Edition, Boston: McGraw-Hill; 2003.

49. Zeithaml VA, Bitner MJ, Gremler DD. Service marketing: Integratingcustomer focus across the firm, $4^{\text {th }}$ Edition, Boston: McGraw-Hill; 2006.

50. Szymanski DM, Henard DH. Customer satisfaction: A meta-analysis of the empirical evidence. Journal of the Academy of Marketing Science. 2001; 29(1):16-35.

51. Athanassopoulos A, Iliakopoulos A. Modeling customer satisfaction in telecommunications: Assessing the effects of multiple transaction points on the perceived overall performance of the provider. Production and Operation Management. 2003;12(2):224-245.

52. Sureshchandar GS, Rajendran C, Kamalanabhan TJ. Customer perceptions ofservice quality - a critique. Total Quality Management. 2001;12:111-24.

53. Ladhari R. Assessment of the psychometric properties of SERVQUAL in the Canadian banking industry. Journal of Financial Services Marketing. 2009;14(1): 70-82.

54. Hazlina AK, Nasim R, Reza M. Impacts of service quality on customer satisfaction: Study of Online banking and ATM services in Malaysia. International Journal of Trade. Economics and Finance. 2011; 2(1):1-9.

55. Cui CC, Lewis BR, Park W. Service quality measurement in the banking sector in
South Korea. The International Journal of Bank Marketing. 2003;21(4/5):191-201.

56. Johnson $R L$, Tsiros $M$, Lancioni RA. Measuring service quality: A system approach. Journal of Services Marketing. 1995;9(5):6-19.

57. Atkinson A. Answering the eternal question: What does the customer want? The Cornell Hotel and Restaurant Administration Quarterly. 1988;29(2):1214.

58. Knutson B. Frequent travellers: Making them happy and bringing them back. The Cornell Hotel and Restaurant Administration Quarterly. 1988;29(1):8387.

59. Choi TY, Chu R. Determinants of hotel guests' satisfaction and repeat patronage in the Hong Kong hotel industry. International Journal of Hospitality Management. 2001;20:277-297.

60. Pollack BL. Linking the hierarchical service quality model to customer satisfaction and loyalty. Journal of Services Marketing. 2009;23(1):42-50.

61. Ghotbabadi AR, Rohaizat B, Setareh F. A review of service quality models. UTM. $2^{\text {nd }}$ International Conference on Management (2nd ICM 2012) Proceeding; 2012.

62. Dillon WR, Madden T, Firtle N. Essentials of Marketing Research. Homewood: Irwin; 1993.

63. Gates R, McDaniel C. Marketing research essentials. $2^{\text {nd }}$ Edition. Ohio: South Western College Publishing; 1998.

64. Pallant J. SPSS: A Step by Step guide to Data Analysis Using SPSS for Windows (Version 16). Crows Nest: NSW: Allen \& Unwin; 2007.

(c) 2016 Ndikubwimana and Berndt; This is an Open Access article distributed under the terms of the Creative Commons Attribution License (http://creativecommons.org/licenses/by/4.0), which permits unrestricted use, distribution, and reproduction in any medium, provided the original work is properly cited.

Peer-review history:

The peer review history for this paper can be accessed here: http://sciencedomain.org/review-history/14667 